DOI: 10.19112/2413-6174-2021-S1-26

\title{
ВИДОВОЙ АНАЛИЗ МЕДИ У КРУПНОГО РОГАТОГО СКОТА В ЗАВИСИМОСТИ ОТ УРОВНЯ НАКОПЛЕНИЯ СВИНЦА
}

\author{
С.В. Нотова ${ }^{1,2}$, О.В. Маршинская ${ }^{1,2} *$, Т.В. Казакова ${ }^{1,2}$ \\ ${ }^{1}$ Федеральный научный центр биологических систем и агротехнологий РАН, г. Оренбург, Россия \\ ${ }^{2}$ Оренбургский государственный университет, г. Оренбург, Россия \\ *e-mail: m.olja2013@yandex.ru
}

РЕЗЮМЕ. Несмотря на то, что конкретные механизмы оборота металлов у крупного рогатого скота изучены, данные об особенности связывания меди в сыворотке крови с высокомолекулярными и низкомолекулярными лигандами у жвачных животных не исследованы. Проведена оценка металл-лигандного гомеостаза меди (species analysis) в сыворотке крови молочных коров в зависимости от уровня накопления свинца. Для формирования групп сравнения выделяли животных с низконормальными значениями (концентрация Рb в крови до 25-го процентиля) и высоконормальными значениями (концентрация Рb в крови выше 75-го процентиля). В сформированных группах проводили сравнение результатов species analysis. Оценку содержания свинца и анализ форм меди выполняли посредством разделения сыворотки крови на фракции с последующим определением содержания металлов в каждой фракции методом ИСП-МС (on-line режим). В качестве элемент-специфического детектора для определения форм связывания марганца в сыворотке крови использовали ИСП-MC NexION 300D. Полученные данные свидетельствуют о том, что изменение уровня меди даже в диапазоне нормальных значений сопровождается перераспределением меди по различным белковым фракциям.

КЛЮЧЕВЫЕ СЛОВА: микроэлементы, крупный рогатый скот, видовой анализ, медь, свинец.

\section{COPPER SPECIES ANALYSIS IN CATTLE DEPENDING ON THE LEVEL OF LEAD ACCUMULATION}

\author{
S.V. Notova ${ }^{1,2}$, O.V. Marshinskaia ${ }^{1,2 *}$, T.V. Kazakova ${ }^{1,2}$ \\ ${ }^{1}$ Federal Research Centre of Biological Systems and Agrotechnologies RAS, Orenburg, Russia \\ ${ }^{2}$ Orenburg State University, Orenburg, Russia \\ *e-mail: m.olja2013@yandex.ru
}

\begin{abstract}
Despite the fact that the specific mechanisms of metal turnover in cattle have been studied, data on the specific binding of iron in blood serum with high-molecular and low-molecular ligands in ruminants have not been studied. For this purpose, the metal-ligand homeostasis of copper (species analysis) in the blood serum of dairy cows was evaluated depending on the level of lead accumulation. To form comparison groups, animals with low-normal values (Pb concentration in the blood up to the $25^{\text {th }}$ percentile) and high-normal values ( $\mathrm{Pb}$ concentration in the blood above the $75^{\text {th }}$ percentile) were isolated. In the formed groups, the results of the species analysis were compared. The assessment of the lead content and the analysis of copper forms was performed by dividing the blood serum into fractions, followed by the determination of the metal content in each fraction by the ICP-MS method (on-line mode). The NexION 300D ICP-MS was used as an element-specific detector for determining the forms of manganese binding in blood serum. The obtained data indicate that the change in the $\mathrm{Cu}$ level, even in the range of normal values, is accompanied by a redistribution of $\mathrm{Cu}$ in different protein fractions.
\end{abstract}

KEYWORDS: trace elements, cattle, species analysis, copper, lead.

\section{ВВЕДЕНИЕ}

Развитие методов аналитической химии привело к пониманию того, что общая концентрация химических элементов не может предоставить полную информацию об их воздействии на живые организмы (Michalke, 2003). Несмотря на то, что конкретные механизмы оборота металлов у крупного рогатого скота изучены, данные об особенности связывания медив сыворотке крови с высокомолекулярными и низкомолекулярными лигандами у жвачных животных не исследованы (Сabrera et al., 2008). Изучение элементного статуса организма является важным инструментом многих исследований, поскольку в здоровом организме гомеостаз всех металлов жестко контролируется, а его нарушение является причиной или следствием многих изменений. 
Цель работы - оценка металл-лигандного гомеостаза меди (species analysis) в сыворотке крови молочных коров в зависимости от уровня накопления свинца.

\section{МАТЕРИАЛЫ И МЕТОДЫ}

Для формирования групп сравнения выделяли животных $\mathrm{c}$ низконормальными значениями (концентрация $\mathrm{Pb}$ в крови до 25-го процентиля) и высоконормальными значениями (концентрация $\mathrm{Pb}$ в крови выше 75-го процентиля). В сформированных группах проводили сравнение результатов species analysis. Оценку содержания свинца и анализ форм меди выполняли посредством разделения сыворотки крови на фракции с последующим определением содержания металлов в каждой фракции методом ИСП-МС

(on-line режим). В качестве элемент-специфического детектора для определения форм связывания марганца в сыворотке крови использовали ИСП-MC NexION 300D.

\section{РЕЗУЛЬТАТЫ И ОБСУЖДЕНИЕ}

Содержание $\mathrm{Cu}$ в сыворотке крови всех животных находилось в интервалах физиологической нормы. Определение форм $\mathrm{Cu}$ в группах животных с различным уровнем накопления свинца показало, что содержание $\mathrm{Cu}$ во фракции $\alpha$-2-макроглобулин (тетрамер) было статистически значимо в 11 раз ниже $(p<0,05)$, при этом содержание $\mathrm{Cu}$ во фракции $\alpha$-2-макроглобулин (димер) было достоверно выше в 2 раза $(p<0,05)$ относительно группы с более высоким уровнем свинца. Данные различия были одинаково выражены и достоверны как при оценке абсолютных величин (мкг/мл), так и при оценке процентного вклада данных форм в сывороточную концентрацию меди.

\section{ВЫВОДЫ}

Полученные данные свидетельствуют о том, что изменение уровня $\mathrm{Cu}$ даже в диапазоне нормальных значений сопровождается перераспределением $\mathrm{Cu}$ по различным белковым фракциям. Таким образом, определение конкретных металлосвязывающих видов в сыворотке крови является ценным инструментом для оценки питательных или токсикологических эффектов металла, что свидетельствуето высоком потенциале применения speciation analysis в лабораторной диагностике нарушений обмена элементов в организме и позволяет прогнозировать и проводить коррекцию обмена элементов на ранних этапах.

Исследования выполнены в соответствии с планом НИР на 2019-2021 гг. ФГБНУ ФНЦ БСТ РАН (№ 05262019-0001).

\section{Сиисок литературы / References}

1. Michalke B. Element speciation definitions, analytical methodology, and some examples. Ecotox Environl Safe. 2003; 56:122-139.

2. Cabrera A., Alonzo E., Sauble E., Chu Y.L., Linder M.C., Sato D.S., Mason A.Z. Copper binding components of plasma and cytoplasm, copper turnover and excretion, as determined in the mouse with large doses of $65 \mathrm{Cu}$. Biometals. 2008; 21: 525-543. 